\title{
Invoking learner voice and developing leadership: what matters to learners?
}

\section{Callie Grant}

\begin{abstract}
Educational leadership and management (ELM) research overly focuses on adult leadership development at the expense of leadership of learners. Framed by the concept of learner voice, this article focuses on learner leadership and argues that learners should be treated as people whose ideas matter. It draws on a Bachelor of Education Honours (ELM) elective which required students (practicing teachers) to establish school leadership clubs and involve learners in a reform initiative in pursuit of leadership development. The longitudinal study which informed this article was designed as a multi-case study to explore learner voice and the development of leadership across 44 leadership clubs drawing on three data sources. The study found that while the phenomenon of learner leadership was not common across schools, leadership clubs offered a space for the development of learner voice. Learner voice was generated in relation to the school physical environment, English proficiency amongst learners, improved learner conduct, developments pertaining to the extra-mural curriculum, and leadership training initiatives. In addition, the clubs afforded learners the opportunity to initiate and lead a change project in their schools. However, the take-up of learner leadership as a whole school initiative was problematic in the majority of schools. The article concludes with some suggestions for a future research agenda emerging out of the first phase of the project.
\end{abstract}

\section{Background and context}

Schools are not working for the majority of our South African youth. We hear, all too often, of the academic crisis in schools; inequalities in educational provision, high failure rates, an increasing learner dropout rate, abysmal Mathematics results and levels of illiteracy pervading the system (Department of Basic Education (DBE), 2011; Christiansen, 2012; Rembe, 2012; Collins, 2015). In an attempt to redress the inequalities of apartheid, the South African education system has undergone wave after wave of curriculum redesign whilst, simultaneously, pursuing the global trend of standardisation, measurement and high stakes testing (Maistry, 2014). Surrounded by discourses of performativity and competition, schools are under enormous pressure to improve learner achievement which has narrowed the purpose of 
schooling, not only in terms of pedagogy and content but also democratic participation (Mitra and Gross, 2009). Westheimer and Kahan (2003) describe how there has been a "shrinking of opportunities for students to have a democratic voice in the educational process" (in Mitra and Gross, 2009, p.525). Consequently, many youth, particularly those who feel their lives, beliefs and hopes are devalued and 'othered' by schooling and the curriculum, develop hostility to the institution of schooling (Mitra and Gross, 2009). As Jones (1996) so poignantly writes, many youth "have crawled beneath the blanket of despair and are suffocating from a lack of human connections" (in Smyth, 2006a, p.280).

Yet in the context of Australia, Smyth argues that the so-called dropout problem is mislabelled; for him student dropout is a result of "a lack of system and societal care, respect and indifference towards young people" (2006a, p.283). This too is the case in South Africa where the academic crisis in schools is a consequence of an uncaring and degenerating societal system. We are a society which has lost its moral compass (Ramphele, 2008) and the group most affected are the youth and particularly those marginalised through poverty, illiteracy, HIV and AIDS and lack of access to the most basic of human resources (Ramphele, 2008; Wood and Goba, 2011; Williams, 2012). It is these learners who most need to be supported and engaged in schooling who are now most likely to be "disillusioned, ignored and even denigrated by the schooling system" (Angus, 2006, p.370). However, it is precisely these marginalised learners who school leaders need to reach out to, engage with and learn to understand and accommodate in schools.

As early as 1982, the Canadian Fullan asked "what would happen if we treated the learner as someone whose opinion mattered in the introduction and implementation of reform in schools" (in Osberg, Pope and Galloway, 2006, p.329). Building on this idea, Osberg et al. ask the thought-provoking question: "How can schools involve students in the introduction and implementation of school reform in ways that best serve them as learners and potential leaders?" (p.343). In direct response to these questions, I want to build a case for the development of authentic learner leadership as one possible way to turn schools around. 


\section{Leadership and learner voice}

While leadership is a concept that is well-studied, research regarding adolescent leadership development is limited (Whitehead, 2009). This is particularly so in South Africa where learner leadership rarely features on the educational agenda and the voices of learners are, more often than not, ignored (Mabovula, 2009). In the context of this article, leadership is understood to be relational, a dialectical process which engages the human agency of all members of the organisation (Gunter, 2005; Angus, 2006). Based on dialogue and strong relationships, it is transformative and "can provide opportunities for all children to learn in school communities that are socially just and deeply democratic" (Shields, 2004, pp.109-110). Thus it is ethical in nature and its moral purpose is to promote the core values of social justice, democracy and equity in the social institutions of schools (Foster, 1986; Smyth, 2006b; Starratt, 2007). Framed in this manner, leadership cannot be reduced to managerial coercion but requires of one the courage to buck the rules, challenge the status quo and "worry more about engaging young people in schooling than managing their behaviour" (Angus, 2006, p.376).

Because of the dialogical nature of leadership, the voices of learners are integral to any discussion on learner leadership. The international literature refers to the voices of learners as 'student voice' and the concept is used to describe the range of ways in which learners can share in decision-making in schools - the kinds of decisions that will shape their lives and the lives of their peers (Fielding, 2001; Mitra and Gross, 2009). However, because South Africa uses the term 'learner' to refer to school-going youth, I have chosen to use the concept of 'learner voice' rather than 'student voice' in the context of my work. Learner voice is about true democracy within institutions (Shuttle, 2007) and it is a potential catalyst for student agency. As Mitra and Gross (2009) contend, learner voice initiatives "can broaden the scope of who has a voice in schools and can even lead to student participation in developing school reform efforts" (p.538). However, they explain that schools tend to teach learners to be passive participants in a democracy rather than leaders. Teachers and parents generally speak too readily on behalf of learners and often misunderstand or disregard their perspectives (Fielding, 2001). And, as Mabovula (2009) claims, when learners are given a voice, it is often a mere 'stamp of approval' rather than a commitment to democratic participation. 


\section{The establishment of learner leadership clubs as a service learning initiative}

While research has been growing on the topic of student voice in the international arena (Fielding, 2001; Flutter, 2006; Mitra, 2006; Whitehead, 2009; Mitra and Gross, 2009) it is limited in South Africa and other African countries (Mabovula, 2009; Uushona, 2013). Prompted by the need for research on learner voice and leadership development in South Africa and guided by the questions raised towards the end of the previous section, I redesigned the ELM Honours elective at Rhodes University with a learner leadership focus. The elective was designed as a service learning initiative, i.e. a teaching and learning strategy which linked the academic learning of the Honours students with a community service experience (Council on Higher Education, 2006; Hart, 2006). To clarify, these Honours students were experienced professionals, studying on a part-time basis while holding down full-time jobs in educational institutions such as schools. Thus the elective was designed as a credit-bearing educational experience which required the students to participate in an organised service activity in their institution and reflect on it in such a way as "to gain further understanding of course content, a broader appreciation of the discipline, and an enhanced sense of civic responsibility" (Bringle and Hatcher, 1996, p.222).

From the outset, the service activity set out expressly to treat learners as a serious constituent of the school community. Like Smyth (2006a), I was confronted with the question of how best to create the spaces within which forms of leadership could be exercised which incorporated the aspirations of learners. Learner leadership clubs offered such a space of leadership from which learners could 'speak back' concerning what they considered important about their learning. Thus these clubs were strategically positioned inside each of the schools of the Honours students and organised as an extracurricular service learning activity for selected groups of learners. Mitra (2006) reminds us that the way one organises a learner voice group when attempting to make school reforms is critical to the outcome. A leadership club as a structure should not be confused with the legislated 'Representative Council of Learners' (RCL) which can now be found in the majority of the country's secondary schools. In contrast to the RCL, participation in the afterschool clubs was voluntary and membership differed from school to school. Furthermore, learner voice efforts through the mechanism of the clubs were 
categorically different from the traditional school roles located within the RCL (Mitra and Gross, 2009).

The purpose of the clubs was that of leadership development which, as Whitehead explains, requires "a multifaceted approach, which includes techniques that range from formal academic processes to experiential development, or what is described as leadership development within the context of work" (2009, p.856). In the schooling context, the clubs provided learners with opportunities to develop their voice in a space in which they would 'be heard', develop their leadership and "learn how to become citizens prepared to actively engage in their communities and participate in democracy" (Mitra and Gross, 2009, p.522).

The design of the elective and the interventionist approach chosen was informed by the work of Mitra and Gross (2009) and their 'pyramid of student voice'. Their pyramid is designed as a three level structure to illustrate youth opportunities possible as learner voice is increased in a school (Figure 1).

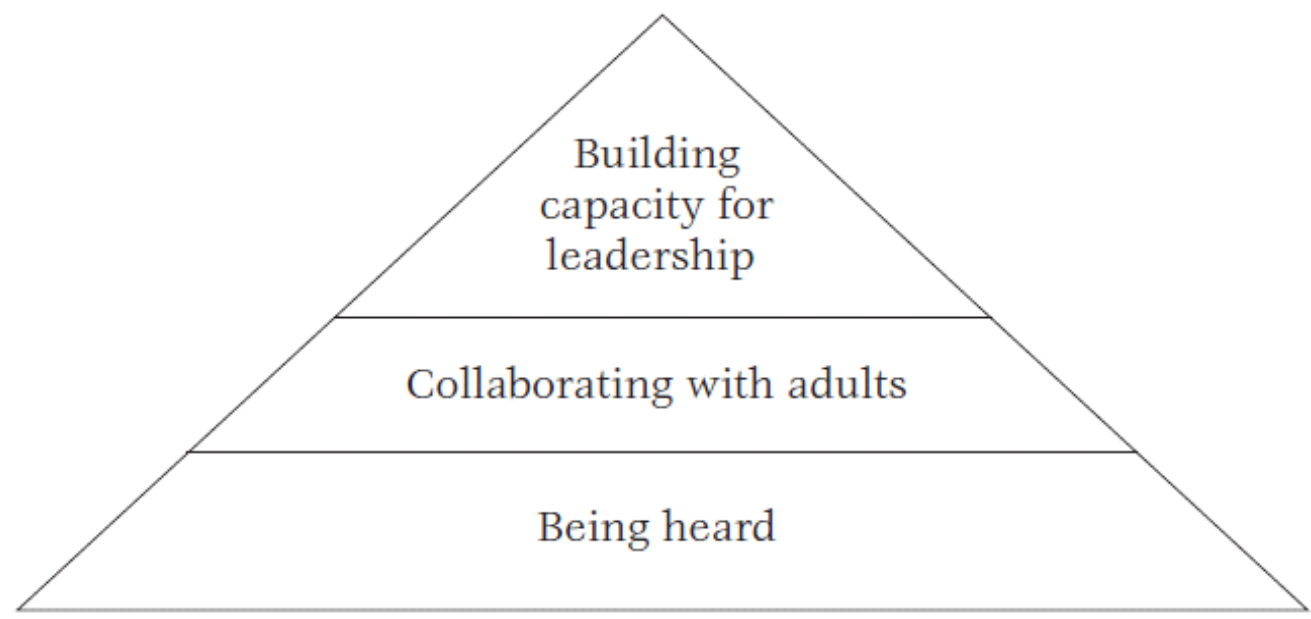

Figure 1: Pyramid of student voice (Mitra and Gross, 2009, p.523)

The pyramid begins at the bottom with the most basic (and most common) form of learner voice - 'being heard'. In the context of the Honours elective, this meant that the Honours student, a teacher in the school, listened to learners through the mechanism of the learner leadership club to learn about their experiences at school and what mattered to them. This was achieved by getting the learners in the club involved as co-researchers in a simple learner survey. Club learners were first assisted by the Honours student to design a questionnaire in response to the following two research questions: 
(i) What knowledge, skills and attitudes do learners need in order to be able to lead authentically in educational institutions?

(ii) What can be learnt from learners about what matters to them in their institutions?

Next, club members distributed the questionnaires to learners in their grade and were responsible for the collection of the completed questionnaires. The Honours student then assisted the members of the club to analyse the data in response to the research questions. Thereafter, the club members, with the help of the Honours student, determined the top five common 'areas that mattered to learners', in order of priority, in response to the second research question. From this list, the Honours student guided the learners in selecting the priority area which would become the focus of the club for the remainder of the year. Selection depended on the priority area being doable (in terms of time, resources and person power) and maintaining the interest and enthusiasm of the learners for an extended period of time (seven months).

The second level of the 'pyramid of student voice' involves the phase of 'collaborating with adults' (Mitra and Gross, 2009, p.523). In the context of the Honours elective, this level involved the Honours students working with their club members to plan an intervention to address the focus area identified and implement the plan over the remainder of the year. Important to note is that the intervention was intended to be learner-driven rather than teacherdriven. Guided by Shuttle's (2007) typology of learner involvement in decision-making, rather than informing learners about or consulting them in order to support a decision, the intervention attempted to create an authentic and collaborative space in which decisions were shaped and owned by learners.

Smyth (2006a) has developed what he regards as the minimalist scaffolding necessary for the construction of spaces of leadership within which forms of leadership can be exercised. Three of his ideas were particularly pertinent in the development and exercise of leadership through the clubs in this study: firstly, there was a need to support the Honours students in their role as teachers in giving up some control and handing it over to learners; secondly, there was discussion about the importance of fostering an environment in which learners are treated with respect and trust rather than fear and threat of retribution; and finally, there was an emphasis on cultivating an atmosphere of care built around relationships (Smyth, 2006a, p.282). 
The final (and smallest) level at the top of the pyramid, 'Building capacity for leadership', includes an explicit focus on enabling youth to 'share in the leadership of the student voice initiative' (Mitra and Gross, 2009, p.524). This final level, Mitra and Gross (2009) argue, is the least common form of learner voice. At this level, learners can serve as a source of criticism and protest in schools by questioning issues such as cultural and structural injustices in the school. As will be seen from the ensuing discussion, the first phase of this project was designed with the purpose of exploring learner voice at the first two levels of the pyramid. The second phase of the project aims to take an indepth look at these first two levels and then it will attempt an exploration of learner voice at this third level of the pyramid. With this in mind, I now move on to discuss the research project which underpins this article.

\section{The research}

The research which underpins this article is part of a larger research project exploring learner leadership in schools in South Africa and Namibia. The project was designed as a longitudinal study to track the Honours ELM elective at the university over a four year period (2013-2016). A qualitative, multi-case study approach was adopted in trying to answer the following research question: Do learner leadership clubs (as an extramural activity) contribute to the development of leadership in schools and, if so, how? As already mentioned, the first phase of the project was designed with the purpose of exploring learner voice at the first two levels of the pyramid. This first phase drew on two case studies; the first, a group of 12 learner leadership clubs drawn from the BEd Honours (ELM) elective offered in Grahamstown, South Africa in 2013 and the second a group of 32 learner leadership clubs drawn from the elective offered in Okahandja, Namibia in 2014. Participants in the first phase of the project included the two groups of Honours students, 44 participants in total. Data were generated from three different sources: first, the 44 academic journal articles which the students submitted as a major part of their assessment for the elective; second, the student self-reflective journals (the DP requirement for the elective) and third, two focus group interviews (FGI), one with a group of South African students and the other with a group of Namibian students. Thematic content analysis was used to analyse the data. 
This first phase of the project offered a breadth of understanding on the topic at hand, an overview of what mattered to learners in schools. However, this first phase relied on the voices of teachers to speak on behalf of the learners; it did not access learner voice directly. Thus, the second phase of the project, which is not yet completed, aims to select a sample of clubs from the first two case studies and do an in-depth analysis of learner voice and leadership development across all three levels of the student voice pyramid in a small number of schools. In this second phase, learners themselves will be a significant participant group.

The purpose of this article, however, is to share the learning from the first phase of the project, and particularly what was learnt from the exploration of learner voice at the first level of the pyramid, 'being heard' (Mitra and Gross, 2009). I show, by means of two case studies (the South African and Namibian cases), what really mattered to learners and the ways in which learners shared in decision-making and participated in school change initiatives.

\section{Discussion \\ What mattered to learners?}

The South African case study

In the South African case study, 12 Honours students were involved in the design and implementation of learner leadership clubs as an extra-mural service learning activity in schools during the 2013 academic year. Of the schools involved, two were private city schools, one was a private rural school and rural public schools made up the balance. Regarding the constitution of the clubs, 11 clubs involved high school learners with only one club involving primary school learners. As discussed earlier, the focus area selected by each of the clubs denoted the priority area which 'mattered to learners' and which emerged during the survey done by learners during the initial stage of the initiative. These areas can be categorised in a number of different ways and so Table 1 is thus partial and represents but one way of organising them. Table 1 uses four categories and a number of sub-categories to group these focus areas. 
Table 1: What mattered to South African learners?

Categories and sub-categories of learner leadership club foci

\begin{tabular}{|l|l|c|}
\hline \multicolumn{1}{|c|}{ Category } & \multicolumn{1}{|c|}{ Sub-Category } & \multicolumn{1}{|c|}{$\begin{array}{c}\text { No. of } \\
\text { students }\end{array}$} \\
\hline $\begin{array}{l}\text { Physical Environment } \\
\text { (Total 6) }\end{array}$ & $\begin{array}{l}\text { A cleaner environment, anti-littering and recycling } \\
\text { Maintenance (repair and repaint) of hand tennis court } \\
\text { Addressing water problems }\end{array}$ & $\begin{array}{c}\text { (1) } \\
1\end{array}$ \\
\hline $\begin{array}{l}\text { Leadership Training } \\
\text { (Total 4) }\end{array}$ & Peer mentoring/twinning & 2 \\
& Inviting learner voice \\
Learner Conduct & Opening communication channels & 1 \\
\hline Total 1) & Drug and substance abuse intervention programme & 1 \\
\hline $\begin{array}{l}\text { English Proficiency } \\
\text { (Total 1) }\end{array}$ & Literacy intervention programme & 1 \\
\hline
\end{tabular}

In the context of the United Kingdom, Flutter's (2006) research has shown that, for her young learners, "the school environment emerged as one of the most important factors affecting the quality of students' learning in school" (p.184). In line with Flutter's research, the physical environment emerged as an important factor in the South African case study with half of the interventions ( 6 of a total of 12) focusing broadly, in some way or another, on this area. Four of these six clubs were interested in creating a cleaner school environment and they did this through campaigns to do with anti-littering and recycling. The fifth club aimed, through its intervention, to address the water problems facing the school while the focus of the sixth club was the repair and painting of the hand tennis court. This focus on the school environment is unsurprising given the poor condition of the majority of our South African school buildings. Like Flutter (2006), I contend that the general poor condition of many school buildings reveals the low status assigned to learners and symbolises a lack of commitment to their education, a message which is not lost on learners. It stands to reason then, that this would be an area which learners would like to change.

The next most common category consisted of four (of 12) focus areas, all of which had to do with leadership training of some form or another. These included two peer mentoring/twinning initiatives, an initiative aimed generally to invite learner voice and a final one which attempted to open 
communication channels between the learners and the management team. One leadership club in this case study focused on a drug and substance abuse intervention programme which I categorised as learner conduct whilst the final club focused on a literacy intervention programme which I placed in the category of English proficiency.

\section{The Namibian case study}

In the Namibian case study, 32 Honours students were involved in the design and implementation of learner leadership clubs as an extra-mural service learning activity in schools during the 2014 academic year. While a couple of the Honours students taught in the local public schools in Windhoek, the majority taught in schools in small rural towns and deep rural villages in the lower socio-economic northern regions of Namibia. As with the South African case study, the majority of the Namibian clubs (29) were located in high schools with only three clubs in primary schools. This statistic across both case studies must give us pause for thought. What does this statistic suggest about the selection process used in our B Ed Honours qualification? Why are so few primary school teachers (both Foundation Phase and Intermediate Phase) selected for the Honours programme? What does this mean for the development of teachers in these critical phases? Whilst these questions are beyond the scope of this article, they are crucial and further investigation thereof is essential.

With regard to the Namibian case study, Table 2 represents my categorisation of the 32 Namibian learner leadership clubs. Table 2 uses four categories and a number of sub-categories to group the 32 focus areas. Three of the four categories overlap with the categories in the South African case study. 
Table 2: What mattered to Namibian learners?

Categories and sub-categories of learner leadership club foci

\begin{tabular}{|l|l|c|}
\hline \multicolumn{1}{|c|}{ Category } & \multicolumn{1}{|c|}{ Sub-Category } & \multicolumn{1}{|c|}{$\begin{array}{c}\text { No. of } \\
\text { students }\end{array}$} \\
\hline $\begin{array}{l}\text { English Proficiency } \\
\text { (Total 16) }\end{array}$ & Speaking, reading and writing English & 8 \\
& Library access and functionality \\
Academic performance (including homework club, & 4 \\
learning skills) & 4 \\
\hline Learner Conduct & Drug and substance abuse intervention programme & 2 \\
(Total 10) & Bullying & 2 \\
& Late coming and absenteeism & 2 \\
& Ill-discipline & 2 \\
& Uniform & 1 \\
& Learner pregnancy & 1 \\
\hline $\begin{array}{l}\text { Physical Environment } \\
\text { (Total 3) }\end{array}$ & Littering campaign & 2 \\
\hline Extra-curricular & Tree planting & 2 \\
(Total 3) & Introducing an extra-mural sporting activity & 1 \\
\hline
\end{tabular}

Unlike the South African case study, the Namibian case did not centre on the physical environment of the school as its main category. In fact, only three clubs had focus areas which fitted into this category (two which adopted, as their initiatives, littering campaigns and the third which attended to tree planting as the club project). Instead, the most common category (in the Namibian case study) was English proficiency with an overwhelming 16 of the 32 focus areas fitting into this category. Eight of these sixteen clubs were interested in the speaking, reading and writing of English. Interest in reading was also apparent in a further four clubs in this category; these clubs focused on ensuring that their previously dysfunctional school libraries were up and running, accessible to learners and staffed by themselves as learner leaders. Academic performance through developing homework clubs and improving learning skills was a central focus for the remaining four clubs in this category.

The next most common category consisted of ten (of 32) focus areas, all of which had to do with learner conduct in some form or another. This category was populated with intervention programmes which addressed drug and 
substance abuse, bullying, late coming and absenteeism, ill-discipline, appropriate wearing of the school uniform and learner pregnancy. The final category involved extra-curricular initiatives ( 3 of 32) including the introduction of new sporting codes in the schools as well as a focus on improving the RCL election campaign at a particular school.

\section{What was learnt from these two case studies?}

From the first phase of the research project, I was able to identify five key areas of learning about learner voice and leadership in the context of our African case studies.

Firstly, the phenomenon of learner leadership was not common across the two case studies. One Honours student was of the view that "it's an area that has been overlooked so obviously, in my experience at least, I haven't seen a lot of it in many schools. . . so it won't be easy to just enforce it; you have to make them accommodate it slowly" (FGI, 2013). The newness of the topic to another student was apparent in the following excerpt: "I enjoy this because it's a brand new angle for me; I never had to learn about learner leadership. It's always, as a teacher you must do this, but it's never about the learner. So that was something new" (FGI, 2013). Yet another Honours student spoke of "bringing out the importance of the learner because we take things for granted, that we know what is good for the learners and, as a result, they resist" (FGI, 2013).

Secondly, learner leadership clubs as an extra-curricular activity in the case study schools offered a space for the development of learner voice and leadership. However, these clubs are but one example of a range of structures which can be introduced into schools with a minimum of disruption to draw on and develop leadership in learners. Through the mechanisms of clubs, the importance of healthy relationships amongst learners, and between learners and their facilitating teacher, surfaced. One Honours student explained that "what matters in schools are relationships, because if relationships are working, any programme that can come can be implemented successfully" (FGI, 2013). Another described how, "if learners are given a voice and if the relationship between the learners and teachers is good, there is a harmony in the school and all the beautiful programmes that we try to bring into the school can work out" (FGI, 2013). As a consequence of the club, yet another 
Honours student described how "now I am looking at my learners from another angle, that they have souls, they are human beings of which they have potential. It's just that I have to discover who they are, so basically my growing, or my growth, will enable them to grow as well"' (FGI, 2013).

Thus, as a consequence of the clubs, relations were acknowledged as central to the work of schools. Smyth (2006b), drawing on the work of Warren (2005), calls on schools to invest learners with 'relational power' which refers to "the building of trust within and across a range of groups in schools in ways that enable the development and pursuit of a common vision about how schools can work for all, including those most marginalised and excluded" (p.292). In this study, the introduction of learner leadership clubs in schools provided a mechanism through which teachers worked towards making their learners 'powerful people' (after Smyth, 2006b). The clubs provided the platform for authentic communication and debate amongst learners; they offered a generative and non-threatening space in which learners learnt to lead and they provided the catalyst for the emergence of learner-led school change initiatives.

Thirdly, learners have leadership potential. When given a generative and non-threatening space, learners were able to articulate what good leaders need to know and do and they were also able to list the values that good leaders aspire to. For example, the members of one of the clubs indicated that in order to execute leadership effectively, learners were required to be self-confident and have a high self-esteem. They also included in their deliberations the need to be caring, motivating, committed, accountable, respectful, flexible and honest. The attribute of being 'exemplary' topped their list as the most important leadership trait for learners (student academic journal article). When afforded the opportunity, learners were further able to communicate a vision and then work as a team to initiate a plan of action in response to that vision, with varying levels of autonomy and success.

Thus it would seem that the development of learner voice is the first step in the development of their leadership. However, Angus (2006) challenges us to do more than merely invite learner voice. He calls on school leaders and all teachers to invoke student voice, to "insist upon, enquire into, try to understand, interrogate, and generate student voice as best they can" (2013, p.378). This suggests that the development of leadership is a conscious and active process requiring modelling and teaching. One Honours student made the point that we cannot complain about the youth when we have forfeited our 
responsibility to teach them: "We are not involving them. They are not part of the decision-making. And we are not giving them a part to play. We are not giving them the responsibility" (FGI, 2013). Another Honours student spoke of the different approaches she now adopted with her learners; an internal conversation she had with herself as a reminder to 'do it differently': "I've learnt a lot, how I interact, how (do) I invite them, how (do) I make them participatory, how (do) I make their voices heard" (FGI, 2013).

Whilst it was beyond the scope of the first phase of this research project to investigate the levels of success of the various learner leadership clubs, the second phase of the project is designed with this specific intention in mind. However, the findings of the first phase of the project suggest that, in SubSaharan Africa, learners constitute a latent source of leadership waiting to be tapped. The question that needs to be asked is: How best can we draw on the leadership of learners to assist us in the transformation of our schools?

Fourthly, and having listened to and 'heard' the learners through the mechanism of the leadership clubs, there are a number of issues which mattered to learners in the context of the case study schools. These can be organised broadly into the following categories: i) issues related to the physical environment of schools, ii) a focus on English proficiency amongst learners, iii) improved learner conduct, iv) developments pertaining to the extra-mural curriculum and v) leadership training initiatives. In and of themselves, these focus areas are both appropriate and doable. Furthermore, these 'matters of concern' to learners are not so different from what matters to good teachers. So the challenge for teachers is surely to learn to really listen to what learners have to say, collaborate more with them and create as many opportunities as possible for learners to speak about what truly matters to them. By so doing, teachers are more likely to be able to draw learners in as allies to the education enterprise and work alongside them as agents of change in the education process.

However, and making my fifth point, the take-up of leadership development of learners as a whole school initiative was problematic in the majority of the 44 schools. While permission was granted from the principals and parents for the clubs to operate in the schools (all issues related to access, permission and ethics was formally attended to at the beginning of the project), these clubs were often (mis)understood as the sole domain of the Honours students and viewed as a temporary structure in the school. As a consequence, the Honours students did not receive the full support of the staff and the take-up of learner 
voice and leadership as a whole school initiative failed. One Honours student described how the staff "distanced themselves from the whole process" (FGI, 2014). This was perhaps because "they don't understand and they do not see the importance of it" (FGI, 2014). Another Honours student recounted how her principal did not like the idea of the intervention and warned her about it: "it must not disturb the programme of the school" (FGI, 2014). This same student also had little support from the teaching staff, perhaps for the following reason: "I think the way the principal introduced the whole intervention to the staff room also let them distance themselves from the whole process, and they thought it's just this teacher's thing that she wants for her BEd Honours, and that is her problem" (FGI, 2014).

In retrospect and in line with the view of Mitra (2006), as the coordinator of this learner leadership development initiative, I should have done more preparatory work to convince the schools of the importance of learner voice and leadership and garnered more support for the Honours students. Following Smyth's (2006b) advice, the unit of change should have been the whole school rather than the individual teacher with his/her leadership club. In line with this thinking, Mitra convincingly argues that "before students are accepted as key players in school reform and decision-making, however, the concept of student voice must gain legitimacy amongst powerful stakeholders in the school" (2006, p.315). Drawing on the work of Chan (2000), Whitehead (2009) makes the very real point that leadership development programmes are often not well-integrated into the formal school curriculum.

Thus the challenge facing the university facilitators now during the second phase of the project is to explore ways to get the clubs more integrated into the schools in which the Honours students teach. Rather than it passing for a 'tokenistic activity' (Shuttle, 2007), the goal of the facilitating team is to get learner voice and leadership taken seriously in schools. This calls for increased mobilisation on our part through the sharing of documentation on learner voice and leadership with the teaching staff at the project schools and meeting with some of the school management teams to discuss the importance of our leadership development efforts within this project and beyond. In summary, and in the words of Shuttle, "learner voice should not act as an adjunct to an institution's activities, but needs to be woven into all aspects of the institution, not hierarchically but as networks of engagement, thus paving the way towards a leadership model that is increasingly student-led" (2007, p.45). 


\section{Researching learner leadership: future directions}

\section{Publication opportunities emerging from Phase One}

There are a number of publication opportunities emerging out of this first phase of the project. While all 44 Honours students involved in the 2013 and 2014 case studies submitted academic journal articles (a major component of their elective assessment), about one quarter were of a very high standard. Our plan is to work with a few of these students to get their work into a form which can ultimately be published in academic peer-reviewed journals. To further communicate our research, the idea of an edited book on the development of leadership through the mechanism of the learner leadership clubs is appealing. In envisioning the book, our aim is to invite interested Honours students, drawn from across the South African and Namibian case studies, to contribute chapters in which they will share in their experiences of the leadership clubs they instituted.

Looking across the 44 academic journal articles drawn from the two case studies, there is scope for a meta-analysis of the data. A cursory read of the articles reveals some recurring themes which become immediately evident. The communication of these findings would offer a valuable contribution to this under-researched topic in Sub-Saharan Africa. In addition, this Honours elective has provided the rare opportunity to explore learner leadership as it intersects with teacher leadership. In this regard, the self-reflective journals of the Honours students are particularly rich in tracking the leadership development of teachers as they facilitated the leadership development of their learners. This leadership nexus is a hitherto unexplored area in the local literature.

\section{Research opportunities emerging from Phase Two}

As we proceed with the second phase of the project, a number of research opportunities are envisaged. First, two further case studies will be included in this longitudinal study, a South African one in 2015 and a Namibian one in 2016. Second, there is scope to investigate the levels of success of a sample of learner leadership clubs from the original two cases in terms of their contribution to the leadership development of learners. Third, a few students who completed the Honours ELM elective will retain a learner leadership 
focus and continue with their clubs towards their Masters degree. Fourth, it would be interesting to explore the nature of support needed by teachers to facilitate the development of learner leadership. Would the idea of a critical friend or a buddy system work for the lead teacher? This leads into my fifth point which is about the school conditions necessary for the development of learner leadership. This, in turn, raises the sixth and final point - is there a place for parents in learner leadership development?

\section{Concluding comments}

While student disengagement from schools is an international problem (Mitra and Gross, 2009), this article has argued that learners can be a major contributor to school reform and have a key role to play in the change process. However, as Smyth (2006b) contends, when we fail to place relationships at the centre of schooling and instead focus on performativity and high stakes testing, we weaken our sense of community and trust and alienate increasing numbers of learners, particularly those already disadvantaged. In so doing, we make the reproduction of disadvantage for these learners much more likely and this works counter to the moral purpose of education and educational leadership which is "to promote in schools as social institutions the core values of social justice, democracy, and equity" (Angus, 2006, p.374).

Educational leadership which promotes these core values of social justice, democracy, and equity is difficult work. It requires a transformative approach (following Shields, 2004) which is based on dialogue and strong relationships and the ability to facilitate critical inquiry. Such a leadership approach is essential in order to review existing school practices and promote a just, inclusive and meaningful learning environment for all learners. Thus, the schooling experience needs to leave learners feeling empowered and enriched rather than disillusioned and denigrated. For Angus, the starting point is likely to be when "the school, its teachers and leaders reach out to such children, move to meet them rather than expecting them to adjust to the entrenched school and teacher paradigms, and attempt to engage them in relevant and interesting school experiences in which they can recognise themselves, their parents, and their neighbours" (2006, p.370). 
This article is premised on the idea that the development of authentic learner leadership is critical if we hope to turn schools around. It calls on school leaders and teachers to draw on their own agency and develop strategies to invoke learner voice. This requires of teachers and school leaders "courageous forms of leadership that fearlessly promote the importance of student ownership and student voice in respect of learning" (Smyth, 2006a, p.282).

This article has argued that learner leadership clubs as an extramural activity in schools offers one such strategy to invoke learner voice and develop leadership. The clubs provide the mechanism - they offer a structure through which teachers can reach out to learners, meet them and engage them in relevant and interesting experiences in the complex journey to turn schools around. Club activities are learner-driven and members take on various roles, including that of co-researcher, planner and intervention implementer in the process of becoming leaders, prepared to challenge the status quo but with alternatives (after Smyth, 2006b).

In conclusion, I want to comment briefly on the Honours ELM elective as a university service learning activity and its implications for higher education research and practice. The demanding context of Higher Education in South Africa has placed university lecturers under mounting pressure to find alternative ways to meet their commitments related to teaching, research and community engagement, the three pillars of a traditional university. In order to survive (and thereafter thrive) I have had to work strategically and adopt a more inclusive view of what it means to be a scholar. In line with the thinking of Boyer (1991), I contend that knowledge is acquired "through research, through synthesis, through practice, and through teaching. .." (Boyer 1991, p.11) and that these four scholarships - of discovery, integration, application and teaching - are inextricably linked to each other. Conceptualising the BEd Honours (ELM) elective as a service learning initiative with an explicit research focus (both for the students and for me) was thus a strategy I adopted to integrate my teaching, research and community engagement commitments. Despite some preliminary challenges, this integrated approach has proved successful and the ELM elective, conceptualised as a service learning initiative, has been retained within the Honours curriculum. Time will tell just how much purchase we get from the initiative in terms of school reform and research publication. 


\section{References}

Angus, L. 2006. Educational leadership and the imperative of including student voices, student interests, and students' lives in the mainstream. International Journal of Leadership in Education: Theory and Practice, 9(4): pp.369-379

Boyer, E.L. 1991. Highlights of the Carnegie Report: the scholarship of teaching from 'scholarship reconsidered: priorities of the professoriate'. College Teaching, 39(1): pp.11-13

Bringle, R.G. and Hatcher, J.A. 1996. Implementing service learning in higher education. The Journal of Higher Education, 67(2): pp.221-239.

Christiansen, I.M. 2012. Ready to teach? Reflections on a South African mathematics teacher education programme. Journal of Education, 56: pp.163-194.

Collins, M. 2015. Partners for possibility: how business leaders and principals are igniting radical change in South African schools. Randburg: Knowres Publishing.

Council on Higher Education 2006. Community engagement in higher education. Proceedings of the conference hosted by the Higher Education Quality Committee of the Council on Higher Education and the Community Higher Education - Service Partnerships Initiative of JET Education Services.

Department of Basic Education, South Africa. 2011. South African Country Report. Progress on the implementation of the Regional Education and Training Plan (integrating the second decade of education in Africa and protocol on education and training: SADC and COMEDAFV. http://www.education.gov.za Accessed 5 August 2015.

Hart, S. 2006. Breaking literacy boundaries through critical service-learning: education for the silence and marginalised. Mentoring and Tutoring, 14(1): pp.17-32.

Fielding, M. 2001. Students as radical agents of change. Journal of Educational Change, 2: pp.123-141. 
Flutter, J. 2006. This place could help you learn: student participation in creating better school environments. Educational Review, 58(2): pp.183-193.

Foster, W. 1986. Paradigms and promises: new approaches to educational administration. New York: Prometheus Books.

Gunter, H.M. 2005. Leading teachers. London: Continuum.

Mabovula, N. 2009. Giving voice to the voiceless through deliberative democratic school governance. South African Journal of Education, 29: pp.219-233.

Maistry, S.M. 2014. Neoliberalism: shaping assessment and accountability regimes in South African education. International Journal of Educational Sciences, 6(2): pp.177-186.

Mitra, D.L. 2006. Student voice from the inside and outside: the positioning of challengers. International Journal of Leadership in Education: Theory and Practice, 9(4): pp.315-328.

Mitra, D.L. and Gross, S.J. 2009. Increasing student voice in high school reform; building partnerships, improving outcomes. Educational Management Administration \& Leadership, 37(4): pp.522-543.

Osberg, J., Pope, D. and Galloway, M. 2006. Students matter in school reform: leaving fingerprints and becoming leaders. International Journal of Leadership in Education: Theory and Practice, 9(4): pp.329-343.

Ramphele, M. 2008. Laying ghosts to rest: dilemmas of the transformation in South Africa. Cape Town: Tafelberg.

Rembe, S. 2012. Right of entry reserved: education policy in relation to access and equity. In Motala, S., Dieltiens, V. and Sayed, Y. (Eds). Finding place and keeping pace: exploring meaningful and equitable learning in South African schools. Cape Town: HSRC press, pp.10-19.

Shields, C. 2004. Dialogic leadership for social justice: overcoming pathologies of silence. Educational Administration Quarterly, 40(1): pp.109-132. 
Shuttle, J. 2007. Learner involvement in decision making. In Collinson, D. (Ed.). Leadership and the learner voice, volume four. Lancaster: Centre for Excellence in Leadership, pp.30-48.

Smyth, J. 2006a. Educational leadership that fosters 'student voice'. International Journal of Leadership in Education: Theory and Practice, 9(4): pp.279-284.

Smyth, J. 2006b. When students have power: student engagement, student voice, and the possibilities for school reform around 'dropping out' of school. International Journal of Leadership in Education: Theory and Practice, 9(4): pp.285-298.

Starratt, R. 2007. Leading a community of learners: learning to be moral by engaging the morality of learning. Educational Management Administration \& Leadership, 35(2): pp.165-183.

Uushona, B.A. 2013. Learners' participation in leadership: a case study in a secondary school in Namibia. Unpublished M Ed thesis. Rhodes University.

Whitehead, G. 2009. Adolescent leadership development: building a case for an authenticity framework. Educational Management Administration \& Leadership, 37(6): pp.847-872.

Williams, S. 2012. Beyond access: how can schools respond to the crisis in care? In Motala, S., Dieltiens, V. and Sayed, Y. (Eds). Finding place and keeping pace: exploring meaningful and equitable learning in South African schools. Cape Town: HSRC press, pp.120-134.

Wood, L. and Goba, L. 2011. Care and support of orphaned and vulnerable children at school: helping teachers to respond. South African Journal of Education, 31: pp.275-290.

Callie Grant Faculty of Education Rhodes University 